https://ejournal.uniska-kediri.ac.id/index.php/Diversi

P-ISSN: 2503 - 4804, E-ISSN: 2614 - 5936, DOI : 10.32503

\title{
KEABSAHAN SURAT EDARAN GUBERNUR DIY PA.VIII/No.K.898/I/A 1975 MENGENAI PELEPASAN HAK MILIK ATAS TANAH BAGI WNI KETURUNAN
}

\author{
Adityo Nugroho. ${ }^{1}$ \\ Fakultas Hukum Universitas Brawijaya \\ Jalan MT. Haryono Nomor.169 Malang, Jawa Timur, Indonesia. \\ axil39@gmail.com
}

\begin{abstract}
This research aims at analysing the legality of circular letter of the Governor of DIY PA. VIII/NO.K.898/I/A 1975 on the release of ownership right over property for mixed-blood Indonesian citizen by exploring the origin of the prohibition from the perspective of legit ratio, juridical, sociological, and philosophical foundation. Further, the legality of this circular letter of the Governor of DIY PA. VIII/NO.K.898/I/A 1975 is analysed from the perspective of the Supreme Court Decree No 179 K/TUN/2017 viewed from comparison perspective of Daerah Istimewa Aceh as a special region in Indonesia, and from the perspective of the Right of Owning the State and ended with the policy which is supposed to be made based on Local Government Regulation of Daerah Istimewa Yogyakarta on the making of Local Government Regulation No 1 2013, in the form of the Special Region Regulation.
\end{abstract}

Keywords: Legality; Circular Letter; Daerah Istimewa Yogyakarta.

\begin{abstract}
ABSTRAK
Penelitian ini bertujuan untuk menganalis Kebasahan Surat Edaran Gubernur DIY PA.VIII/NO.K.898/I/A 1975 mengenai pelepasan hak milik atas tanah bagi WNI (Warga Negara Indonesia) keturunan dengan cara menggali landasan yuridis, landasan sosiologis dan landasan filosofis. Kemudian menganalisa kebasahan Surat Edaran Gubernur DIY PA.VIII/NO.K.898/I/A 1975 melalui perspektif Putusan Mahkamah Agung Nomor 179 K/TUN/2017 dilihat dari Perspektif Perbandingan dengan Daerah Istimewa Aceh yang merupakan wilyah istimewa lain yang berada di Indonesia, serta Dilihat dari perspektif Hak mengusai negara dan ditutup dengan Bentuk kebijakan yang seharusnya dikelurkan berdasarkan Peraturan Daerah Daerah Istimewa Yogyakarta tentang cara pembentukan Peraturan Daerah Istimewa Nomor 1 Tahun 2013, dalam bentuk Peraturan Daerah Istimewa.
\end{abstract}

Kata Kunci: Keabsahan; Surat Edaran; Daerah Istimewa Yogyakarta.

${ }^{1}$ Submission : 10 Juli 2019 | Review-1 : 12 September 2019 | Review-2 : 13 September 2019 | Production : 01 November 2019. 


\section{Pendahuluan}

Sejak berdirinya pada abad ke-17, Yogyakarta merupakan salah satu daerah yang dipimpin oleh seorang Sultan, dan sesudah terbentuknya Negara Kesatuan Republik Indonesia (NKRI), Yogyakarta dengan keunikanya serta jasanya yang mendukung kemerdekaan Indonesia tetap diakui melalui Undang-Undang Dasar $1945 .^{2}$

Eksistensi masyarakat adat di Indonesia diakui secara konstitusional sebagaimana tertuang pada Pasal 18 Undang-Undang Dasar Negara Republik Indonesia Tahun 1945 yang menyatakan "Pembagian daerah Indonesia atas daerah besar dan kecil dengan bentuk susunan pemerintahanya ditetapkan dengan Undang-Undang, dengan memandang dan mengingat dasar pemusyawaratan dalam sistem pemerintahan Negara, dan hak asal-usul dalam daerah yang bersifat istimewa". ${ }^{3}$ Berdasarkan peraturan ini maka dibentuklah Undang-Undang yang menetapkan sebagai Daerah Istimewa melalui Undang-Undang Nomor 3 Tahun 1950 yang mengatur mengenai Pembentukan Daerah Istimewa Yogyakarta (DIY) dan diperkuat dengan pembaharuan melalui Undang-Undang Nomor 13 Tahun 2012 tentang Keistimewaaan Daerah Istimewa Yogyakarta.

Sebagai pemegang kekuasaan tertinggi di DIY, Sultan memiliki kontrak politik terhadap rakyatnya untuk mengayomi masyarakat dan penjaga stabilitas di daerahnya. Sebagai pengayom masyarakat Sultan menganggap bahwa masuknya suku pendatang seperti keturunan Tionghoa dan Timur Asing di daerahnya sebagai ancaman nyata yang perlu ditangkal, seperti ancaman berupa penguasaan tanah oleh orang asing.

Tanah dalam kebudayaan Jawa memiliki peran penting seperti yang diungkapkan dalam pepatah "sakdhumuk bathuk sanyari bhumi, ditohi pati, pecahing dhadha wutahing ludira", yang mempunyai makna status tanah dalam masyarakat Jawa yang agararis nilainya setara dengan harga diri manusia yang dicerminkan dengan dahi, akan dikukuhi sampai pecahnya dada, dan tumpahnya

\footnotetext{
${ }^{2}$ Sabda Carakatama, Sejarah Keraton Yogyakarta (Yogyakarta: Narasi, 2019). Hlm. 3

${ }^{3}$ Rachmad Syafa'at, "Politik Hukum Dan Hak-Hak Masyarakat Adat Terhadap Akses Sumber Daya Alam," Cakrawala Hukum 1, no. 2 (2011).
} 
darah. ${ }^{4}$ Dengan keyakinan tersebut Sultan mengeluarkan peraturan di Daerah Istimewa Yogyakarta Hak Milik atas Tanah bagi Warga Negara Indonesia keturunan tidak diperbolehkan.

Larangan ini dituangkan pada Surat Edaran Gubernur Daerah Istimewa Yogyakarta PA.VIII/No.K.898/I/A 1975 yang menyatakan :

"Guna Penyeragaman kebijakan pemberian hak atas tanah dalam wilayah Daerah Istimewa Yogyakarta kepada seorang WNI non Pribumi, dengan ini diminta : Apabila ada seorang WNI non Pribumi membeli tanah hak milik rakyat, hendaknya diproseskan sebagaimana biasa ialah dengan melalui pelepasan hak, sehingga tanahnya kembali menjadi tanah Negara yang dikuasai langsung oleh Pemerintah Daerah DIY dan kemudian yang berkepentingan melepaskan supaya mengajukan permohonan kepada Kepala Daerah DIY untuk medapatkan suatu hak".

Pemerintah seharusnya bisa mencegah adanya kerugian bagi warga Negara dan tidak beralasan bahwa tidak mempunyai kewenangan dan tidak membiarkan terjadinya pertentangan norma antara Peraturan Daerah dengan Undang-Undang Dasar 1945 atau disebut sebagai antinomi hukum.

Antinomi hukum sendiri memiliki pengertian sebagai sebuah istilah bila terjadi sebuah inkonsistensi atau konflik antara dua hal yang setara. ${ }^{6}$ Karena prinsip kewajiban positif Negara timbul sebagai konsekuensi logis dari adanya ketentuan menurut hukum HAM internasional bahwa individu adalah pihak yang memegang HAM sedangkan Negara berposisi sebagai pemegang kewajiban terhadap HAM yaitu kewajiban untuk melindungi, menjamin dan memenuhi HAM setiap individu. ${ }^{7}$ Yang tugas utamanya melayani masyarakat umum tidak hanya memberikan perintah tetapi membantu memecahkan masalah yang ada pada masayarakat dan salah satunya adalah masalah ini, dimana terjadi konflik

4 Tyas Dian Anggraeni, "Interaksi Hukum Lokal Dan Hukum Nasional Dalam Urusan Pertanahan Di Daerah Istimewa Yogyakarta," Jurnal Rechstfinding Media Pembinaan Hukum Nasional, 1, no. 1 (2012). Hlm. 54

${ }^{5}$ Surat Edaran Gubernur Daerah Istimewa Yogyakarta PA.VIII/No.K.898/I/A 1975 tentang Larangan Kepemilikan Tanah Hak Milik Bagi WNI Nonpribumi

${ }^{6}$ E.Fernando Manullang, Menggapai Hukum Berkeadilan (Jakarta: Kompas Gramedia, 2016). Hlm. 25

7 Andrey Sujatmoko, Hukum HAM Dan Hukum Humaniter (Jakarta: Raja Grafindo Persada, 2015). Hlm. 12 
norma antara peraturan daerah dan hukum nasional, pemerintah pusat harus menemukan solusi agar tidak terjadi gugatan atas masalah yang sama.

Penelitian yang membahas tentang Surat Edaran. Gubernur Daerah Istimewa Yogyakarta PA.VIII/NO.K.898/I/A 1975 Mengenai Pelepasan Hak Milik Atas Tanah Bagi WNI Keturunan secara umum belum terlalu banyak dilakukan kajian oleh para peneliti terdahulu. Berdasarkan hasil penelusuran terhadap beberapa literatur yang telah dilakukan, maka setidaknya ditemukan satu literatur berupa Thesis yang membahas mengenai permasalahan ini yaitu Linda Arthaputri Kurniadewi dengan judul Pelaksanaan Surat Edaran Gubernur DIY PA.VIII/NO.K.898/I/A/1975 tentang Larangan Kepemilikan Tanah Hak Milik Bagi WNI Non Pribumi Di Kabupaten Sleman pada tahun 2015.

Dalam penelitiannya tersebut mengkaji tentang pelaksanaan Surat Edaran Gubernur DIY PA.VIII/No.K.898/I/A 1975 tentang Larangan Kepemilikan Tanah Hak Milik Bagi WNI Nonpribumi di Kabupaten Sleman, hal-hal yang melatarbelakangi larangan pemilikan hak milik atas tanah bagi WNI nonpribumi di Kabupaten Sleman, dan untuk mengetahui penyelesaian terhadap permasalahan yang timbul akibat dari larangan hak milik bagi WNI nonpribumi di Kabupaten Sleman. Penelitian ini bersifat deskriptif. Metode pengumpulan data dilakukan dengan penelitian lapangan dengan cara wawancara untuk memperoleh data primer dan penelitian kepustakaan untuk memperoleh data sekunder.

Hasil penelitian dianalisis secara kualitatif dengan seleksi data, pengelompokan data, pensistematisan data, penghubungan data dengan norma dan asas sehingga diperoleh gambaran yang jelas berkaitan dengan permasalahan yang diteliti. Hasil penelitian menunjukan bahwa: Pertama, Pelaksanaan Surat Edaran Gubernur DIY PA.VIII/NO.K.898/I/A 1975 tentang Larangan Kepemilikan Tanah Hak Milik Bagi WNI Nonpribumi di Kabupaten Sleman Sudah berlangsung efektif di Kabupaten Sleman, Kedua, Latar belakang larangan pemilikan hak milik atas tanah bagi WNI nonpribumi di Kabupaten Sleman dikarenakan sejarah terbentuknya Daerah Istimewa Yogyakarta. Ketiga, Penyelesaian terhadap permasalahan yang timbul akibat dari larangan hak milik 
bagi WNI nonpribumi di Kabupaten Sleman adalah: Dalam perjanjian pinjam nama sebagai alat untuk menyimpangi ketentuan larangan hak milik bagi WNI nonpribumi, Kantor Pertanahan Kabupaten Sleman hanya akan melihat nama yang tertulis di sertifikat dan nama yang ada di buku tanah. ${ }^{8}$

Berdasarkan kedua penelitian terdahulu tersebut, maka dapat diketahui bahwa penelitian ini berbeda dengan penelitian tersebut. Adapun perbedaan tersebut terletak pada fokus kajian yang ditawarkan. Seperti yang diketahui bahwa penelitian terdahulu di atas memfokuskan kajian terkait Surat Edaran Gubernur DIY PA.VIII/NO.K.898/I/A 1975 di daerah Sleman sedangkan untuk penelitian ini memfokuskan kajiannya pada Pelepasan Hak Milik Atas Tanah Bagi WNI Keturunan.

\section{Rumusan Masalah}

Berdasarkan latar belakang masalah di atas, maka rumusan masalah dalam penelitian ini yaitu, pertama, bagaimana landasan yuridis, filosofis dan sosiologis Surat Edaran Gubernur PA.VIII/No.K.898/I/A 1975 mengenai pelepasan hak milik atas tanah bagi WNI keturunan. Kedua, apakah Surat Edaran Gubernur DIY PA.VIII/No.K.898/I/A 1975 memiliki keabsahan dan sudah sesuai dengan peraturan perundangan di Indonesia. Serta Ketiga, bagaimana bentuk kebijakan yang seharusnya dikeluarkan oleh Gubernur DIY agar dapat memberikan dasar kewenangan atas tindakanya.

\section{Tujuan Penelitian}

Tujuan penelitian ini untuk menganalisa landasan yuridis, filosofis dan sosiologis Surat Edaran Gubernur PA.VIII/No.K.898/I/A 1975 mengenai pelepasan hak milik atas tanah bagi WNI keturunan. Kemudian menganalisa Surat Edaran Gubernur DIY PA.VIII/No.K.898/I/A 1975 memiliki keabsahan dan sudah sesuai dengan peraturan perundangan di Indonesia serta menganalisa

8 Linda Arthaputri Kurniadewi, "Pelaksanaan Surat Edaran Gubernur DIY PA.VIII/NO.K.898/I/A/1975 Tentang Larangan Kepemilikan Tanah Hak Milik Bagi Wni Non Pribumi Di Kabupaten Sleman,” (Universitas Gadjah Mada, 2015). Hlm. 1 
bentuk kebijakan yang seharusnya dikeluarkan oleh Gubernur DIY agar dapat memberikan dasar kewenangan atas tindakanya.

\section{Metode Penelitian}

Jenis penelitian yang dilakukan adalah yuridis-normatif dengan fokus kajian terletak pada Surat Edaran Gubernur DIY PA.VIII/No.K.898/I/A 1975 tentang Larangan Hak Milik Bagi WNI nonpribumi yang berujung pada keluarnya Putusan Mahkamah Agung Nomor 179 K/TUN/2017. Penelitian yuridis normatif dilakukan dengan meneliti bahan pustaka yang merupakan dokumen dan juga disebut penelitian kepustakaan.

Bahan hukum penelitian ini terdiri atas bahan hukum primer dan bahan hukum sekunder. Bahan hukum primer adalah Peraturan Perundangan yakni Pasal 2 ayat (3) dan (4) Undang-Undang Nomor 5 Tahun 1960 mengenai Pokok Agraria, Pasal 7 ayat (2) dan (3) Undang-Undang Nomor 13 Tahun 2012 tentang Daerah Istimewa Yogyakarta, Surat Edaran Gubernur DIY PA.VIII/No.K.898/I/A 1975 tentang Larangan Hak Milik Bagi WNI nonpribumi, Putusan Mahkamah Agung Nomor 179 K/TUN/2017, Pasal 18B ayat (2) Undang-Undang Dasar 1945 terdapat pengakuan masyarakat adat dan Pasal 3 sampai dengan Pasal 40 Peraturan Daerah Istimewa Yogyakarta tentang Cara Pembentukan Peraturan Daerah Istimewa Nomor 1 Tahun 2013.

Bahan Hukum Sekunder berupa buku literatur, artikel, berita, makalah, factsheet, laporan, Jurnal Ilmiah dan berbagai bahan yang telah diperoleh yang berkaitan dengan hukum pertanahan Bahan hukum sekunder yang diperoleh tersebut dibaca dan ditemukan kaitanya dengan penilitian yang akan diteliti yang selanjutnya akan dipelajari lebih lanjut.

Teknik analisis bahan hukum menggunakan metode kualitatif, yaitu dengan cara menguraikan data dalam bentuk kalimat yang tersusun secara sistematis. Kemudian, sarana atau alat untuk menganalisis Bahan Hukum Primer yaitu menggunakan interpretasi gramatikal, suatu cara penafsiran yang menafsirkan Undang-Undang menurut arti kata-kata (istilah) yang terdapat pada Undang- 
Undang. interpretasi sistematis, kemudian sarana analisis bahan hukum sekunder menggunakan Interpetasi Historis berdasarkan sejarah kenapa larangan tersebut tebentuk. Hasil dari analisis bahan hukum tersebut dipergunakan untuk merumuskan kesimpulan dan saran yang sesuai dengan perumusan pembahasan penelitian. Analisis tersebut dikonfirmasi dalam bentuk dokumen yang diharapkan dapat menjelaskan keabsahan Surat Edaran Gubernur DIY PA.VIII/No.K.898/I/A 1975 yang mengatur mengenai pencabutan hak milik atas tanah bagi WNI keturunan.

\section{Hasil Penelitian dan Pembahasan}

\subsection{Rasio Legis Surat Edaran Gubernur PA.VIII/No.K.898/I/A 1975 Mengenai Pelepasan Hak Milik Atas Tanah Bagi WNI Keturunan}

Landasan yuridis merupakan pertimbangan atau alasan yang menggambarkan bahwa peraturan yang dibentuk untuk mengatasi permasalahan hukum atau mengisi kekosongan hukum dengan mempertimbangkan aturan yang telah ada yang akan diubah atau yang akan dicabut guna menjamin kepastian hukum dan rasa keadilan masyarakat.

Landasan yuridis menyangkut persoalan hukum yang berkaitan dengan substansi atau materi yang diatur sehingga perlu dibentuk peraturan perundang-undangan yang baru. Beberapa persoalan hukum itu, antara lain, peraturan yang sudah ketinggalan, peraturan yang tidak harmonis atau tumpang tindih, jenis peraturan yang lebih rendah dari Undang-Undang sehingga daya berlakunya lemah, peraturannya sudah ada tetapi tidak memadai, atau peraturannya memang sama sekali belum ada.

Terkait landasan yuridis dalam Edaran Gubernur PA.VIII/No.K.898/I/A 1975 mengenai Pelepasan Hak Milik Atas Tanah Bagi WNI Keturunan berdasar pada larangan yang sudah ada semenjak Pemerintah Kolonial Belanda, atas dasar Agraris Wet dan Agraris Besluit (Domeinverklaring) tersebut juga lahir sebuah hukum baru yakni “Grondvervreemdingsverbod" (Stbl. 1875 No. 179) yang melarang 
penjualan tanah oleh orang pribumi kepada bangsa asing demi melindungi rakyat dengan ekonomi lemah.

Ketentuan larangan pengasingan tanah di masa Hindia Belanda ini lahir atas dasar teori van den Berge, bahwa tidak mungkin seorang bukan Indonesia menikmati hak-hak kebendaan atas tanah yang lain daripada yang dikenal dalam Burgerlijk Wetboek (BW). ${ }^{9}$ Larangan pengasingan tanah juga diatur dalam peraturan-peraturan berikut, yaitu:

5.1.1. Stbl. 1872 No. 117, Pasal 19: Agrarisch-eigendom tidak dapat diasingkan kepada orang-orang bukan Indonesia terkecuali dengan penetapan daripada (Hoofd Gewestelijk Bestuur).

5.1.2. Stbl. 1906 No. 83, tanggal 1 Maret 1906 tentang Peraturan Desa (Inlandsche Gementee Ordonnantie).22 Tanah milik rakyat tidak dimungkinkan dioper kepada orang asing, kecuali mendapat izin dari dewan perwakilan rakyat kabupaten.

5.1.3 Stbl. 1912 No. 442, Pasal 12 ayat (7): bahwa tiap-tiap pembebanan, pengasingan, dan penghibahan hak usaha oleh orang Indonesia kepada orang bukan Indonesia (Eropa dan yang dipersamakan dengan orang Indonesia, yaitu Timur Asing).

Kemudian terkait landasan filosofis dari larangan bagi kepemilikan hak atas tanah bagi WNI keturunan dikarenakan masyarakat hukum adat dan tanah mempunyai hubungan erat satu sama lain. Hubungan hukum antara masyarakat hukum adat dengan tanahnya menciptakan hak yang memberikan masyarakat sebagai suatu kelompok hukum, hak untuk menggunakan tanah bagi keuntungan masyarakat walaupun adanya larangan pengasingan tanah orang pribumi kepada orang asing tetapi dalam praktiknya masih terjadi peralihan dengan menggunakan metode pinjam nama, bahkan Daerah Yogyakarta dan Surakrta adalah sasaran pemodal asing untuk membuat perkebunan tebu dan tembakau, tanah untuk

\footnotetext{
${ }^{9}$ Sudargo Gautama, Hukum Agraria Antar Golongan (Bandung: Alumni, 1973). Hlm. 53
} 
onderneming 59.985 ha dengan sistem glebagan, artinya menguasai tanah dua kali lipat dari luas itu.

Daerah Kesultanan Yogykarta penduduknya sangat padat sebelum krisis tahun 1930 disana berdiri 33 Perusahann tebu asing, dan memakai tanah untuk tebu saja (kecuali untuk tembakau dll) 22.819 bau dengan glebagan stelsel, artinya mereka menguasai tanah dua kali lebih luas, dan 513 bau dengan pemakaian tetap (voortdurend gebruik) untuk keperluan bangunan, perumahan, dan tanah-tanah untuk keperluan pabrik. Karena, tanah garapan rakyat sangat kecil. ${ }^{10}$ Dengan besarnya Penggunaan tanah oleh Perkebunan seorang keluarga tani rata-rata hanya mempunyai tanah 1/4 atau 1/3 ha. Di daerah Klaten, di bagian tanah yang sangat subur, tanah garapan rakyat hanya rata-rata $1 / 3$ bau, atau kurang dari $1 / 4$ ha. Di bagian yang tidak subur agak luas sedikit. ${ }^{11}$

Yogyakarta tercatat hanya memiliki luas 3.185,80 km atau 0,17\% dari luas Indonesia (1.860.359,67 km). DIY merupakan provinsi terkecil setelah Provinsi DKI Jakarta. ${ }^{12}$ Seperti yang dibahas pada bab sebelumnya bahwa DIY yang subur tanahnya sudah menjadi incaran berbagai pihak termasuk didalamnya adalah WNA (Warga Negara Asing) yang berinvesatsi dalam bidang perkebunan, dan berakibat pada kepemilikan tanah Pribumi sangat kecil, hal ini terulang kembali pada zaman setelah kemerdekaaan, ancaman berikutnya bukanlah dari pemilik perkebunan akan tetapi investor yang berupaya membangun hotel dan mall, sudah menjadi pengetahuan umum bahwa Yogyakarta adalah kota yang kaya akan warisan budaya dan keindahan alam, hal ini ditambah pula dengan DIY yang menyandang predikat sebagai kota pendidikan. Sehingga menarik investor utuk berinvestasi disana hal ini semakin mendesak warga pribumi di Yogyakarta yang merupakan mayoritas disana.

${ }^{10}$ Mochamad Tauhid, Masalah Agraria Di Indonesia (Yogyakarta: STPNpress, 2009). Hlm. 2009

${ }^{11}$ Mochamad Tauhid. Hlm. 87

12 Pemerintah Daerah Daerah Istimewa Yogyakarta, "Luas Wilayah," 2019, https://jogjaprov.go.id/berita/detail/luas-wilayah. 
Masuknya investor juga membuat harga tanah semakin naik yang menyusahkan warga pribumi untuk membeli tanah hal ini diperparah dengan wilayah DIY yang sempit yang dimana wilayahnya menempati peringkat kedua wilayah provinsi terkecil di Indonesia, beranjak dari argumen inilah maka Surat Edaran Gubernur yang melarang Kepemilikan bagi WNI keturunan berasal. Gubernur saat itu Pakualam melihat bahwa ini merupakan ancaman nyata bagi hajat hidup orang banyak sehingga menegluarkan peraturan tersebut. Penerusnya Sultan Hamengkubowono X walaupun tidak mengelurakan peraturan tersebut tidak mencabut pula peraturan tersebut, ini merupakan indikasi bahwa Sultan Hamengkubowono $\mathrm{X}$ melihat ancaman yang sama, yang mengancam penduduk Pribumi sehingga tidak mencabut peraturan tersebut.

Lebih lanjut terkait dengan landasan sosiologis dari keluarnya Edaran Gubernur PA.VIII/No.K.898/I/A 1975 Mengenai Pelepasan Hak Milik Atas Tanah Bagi WNI Keturunan tersebut adalah Gubernur yang pada saat itu dijabat oleh Pakualam setelah menimbang berbagai faktor dari hal-hal yang telah dijelaskan bahwa terjadi suatu ketimpangan yang terjadi pada masyarakat Yogyakarta dan merasa perlu adanya intervensi Pemerintah Daerah untuk mengembalikan keseimbangan pada masyarakat dengan mengelurkan produk hukum yakni moratorium yang berbentuk surat edaran larangan hak milik atas tanah bagi WNI keturunan di Yogyakrta.

Moratorium teresbut dikeluarkan oleh Pakualam dapat diartikan sebagai sebuah program yang diarahkan untuk kalangan tertentu untuk mengurangi kesenjangan, kalangan tertentu yang dimaksudkan disini bisa berupa ras dalam konteks ini adalah warga primbumi, pertanyaan mengapa pemerintah harus turut campur adalah berasal dari sejarah pemerintah kolonial yang dimana melepas sebagian besar tanah di Daerah Istimewa Yogyakarta kepada Perkebunan asing, seperti yang dijelaskan sebelumnya bahwa Daerah Yogyakarta dan Surakrta adalah sasaran pemodal asing untuk 
membuat perkebunan tebu dan tembakau, Moratorium merupakan suatu tindakan yang tepat yang dilakukan oleh Pemerintah.

Untuk mengurangi kesenjangan walau terlihat tidak adil ini dianggap sebagai sebuah tindakan kompensasi kepada warga pribumi Yogyakarta yang selama Pemerintah Kolonial sebelumnya tertindas, prinsip kompensasi yang dilakukan oleh Pemerintah Yogyakarta ini berdasarkan teori Keadilan distributif, yang dimana compensatory justice mempunyai tujuan untuk mengembalikan keseimbangan antar pihak dengan cara memperbaiki kesalahan tertentu atau mengkompensasi individual untuk tindakan tidak adil yang dilakukan padanya, Moratorium melalui konsep compensatory justice juga mempunyai pengertian pada pemberian keuntungan bagi korban ketidakadilan dengan tujuan meminimalkan atau membalikkan dampak kerugian yang dilakukan oleh ketidak-adilan. ${ }^{13}$ Moratorium ini dianggap sebagai distibusi hak, manfaat dan beban kepada anggota masyarakat dengan cara mendistribusikan beban dan manfaat, keadilan distirbutif mewajibkan individual untuk diberikan keuntungan atau manfaat kepada mereka dalam kondisi yang adil. ${ }^{14}$

\subsection{Keabsahan Surat Edaran Gubernur DIY PA.VIII/No.K.898/I/A 1975}

Dilihat dari perspektif Putusan Mahkamah Agung Nomor 179 K/TUN/2017, bahwa peradilan menganut suatu "Sistem kasasi," yang juga lazim disebut "Sistem kontinental" yang berasal dari Perancis. Berdasarkan sistem tersebut, maka Mahkamah Agung sebagai pengadilan kasasi memiliki tugas membina keseragaman dalam penerapan hukum dan menjaga agar semua hukum dan Undang-Undang di seluruh Indonesia diterapkan secara tepat dan adil. ${ }^{15}$ Maka dapat dilihat bahwa keputusan Mahkamah Agung

\footnotetext{
${ }^{13}$ Mullen Elizabeth, Compensatory Justice, The Oxford Handbook of Justice in the Workplace, (Oxford: Chapter, 2015). H1m. 257

${ }^{14}$ John Rabe, Equality, Affirmative Action And Justice, (Hamburg: Books on Demand GMBH, 2001). Hlm. 91

${ }^{15}$ A. Mukti Arto, Konsepsi Ideal Mahkamah Agung Redefinisi Peran Dan Fungsi Mahkamah Agung Untuk Membangun Indonesia Baru, (Yogyakarta: Pustaka Pelajar, 2001). Hlm. 225
} 
adalah sebuah hal yang relevan untuk dibahas untuk mebuktikan Kebasahan Surat Edaran Gubernur Yogyakarta yang melarang adanya kepemilikan hak atas tanah bagi WNI keturunan dapat dilihat dalam putusan Mahkamah Agung Nomor 179 K/TUN/2017.

Kasus tersebut dimulai dengan pengajuan gugatan oleh seorang warga keturunan Tionghoa bernama Agus Subagio yang berasal dari semarang, Agus Subagio hendak membeli sebuah rumah tinggal yang terletak di kabupaten Bantul dimana rumah tersebut adalah milik WNI pribumi dengan status Hak Milik, Agus Subagio ketika membeli rumah tersebut tidak mengetahui bahwa adanya peraturan di Yogyakarta yang melarang WNI nonpribumi untuk mempunyai Hak milik tanah disana, sehingga Agus Subagio melanjutkan proses jual-beli rumah tersebut dan diserahkanya pada Notaris/PPAT, ketika pengurusan pengurusan jual-beli selesai status tanahnya berubah dari Hak Milik turun menjadi Hak Guna Bangunan.

Disini akan dijabarkan alasan mengapa Mahkmah Agung memenangkan tergugat, alas an serta pertimbangan tersebut adalah :

5.2.1. Keputusan yang menjadi Objek Gugatan tidak termasuk dalam pengertian Keputusan Tata Usaha Negara yang dapat digugat di Pengadilan Tata Usaha Negara;

5.2.1.1. Bahwa berdasarkan Pasal 1 angka 9 Undang-Undang Nomor 51 Tahun 2009 tentang Perubahan Kedua atas Undang Undang Nomor 5 Tahun 1986 tentang Peradilan Tata Usaha Negara, disebutkan bahwa "Keputusan Tata Usaha Negara adalah suatu penetapan tertulis yang dikeluarkan oleh Badan atau Pejabat Tata Usaha Negara yang berisi tindakan hukum Tata Usaha Negara yang berdasarkan Peraturan Perundang-Undangan yang berlaku, yang bersifat konkrit, individual, dan final, yang menimbulkan 
akibat hukum bagi seseorang atau badan hukum perdata". ${ }^{16}$ Unsur-unsur tersebut adalah bersifat kumulatif yang artinya Keputusan Tata Usaha Negara harus memenuhi seluruh unsur unsur tersebut tanpa kecuali;

5.2.1.1.1 Konkrit, artinya objek yang diputuskan oleh Pejabat Tata Usaha Negara itu tidak abstrak, tetapi dapat ditentukan apa yang harus dilakukan. Objek Gugatan masih belum memberikan kepastian apa yang harus dilakukan karena objek gugatan masih berupa instruksi dan bukan perintah sehingga belum memenuhi syarat sebagaimana dimaksud dalam Undang-Undang tentang Peradilan Tata Usaha Negara;

5.2.1.1.2 Individual, artinya Keputusan Pejabat Tata Usaha Negara itu tidak ditujukan untuk umum. Objek gugatan yang berupa instruksi penyeragaman Policy pemberian hak atas tanah kepada seorang WNI non Pribumi, ditujukan kepada umum, tidak ditujukan kepada orangperorang, terbukti cara penyampaiannya tidak diberitahukan atau dikirimkan kepada orang per-orang, pemberitahuannya dilakukan dengan memasukkan pada Tambahan Lembaran Daerah Daerah Istimewa Yogyakarta Nomor 14 Tahun 1975 pada tanggal 5 Maret 1975, oleh karena itu objek gugatan ini tidak memenuhi syarat individual sebagaimana dimaksud dalam UndangUndang tentang Peradilan Tata Usaha Negara;

5.2.1.1.3 Final, artinya Keputusan Tata Usaha Negara sudah definitif, dapat dilaksanakan, tidak memerlukan lagi adanya persetujuan dari Badan atau Pejabat Tata Usaha

${ }^{16}$ Nur Asyiah, Hukum Administrasi Negara (Yogyakarta: Deepublish, 2018). Hlm. 98 
Negara lainya. Objek gugatan yang berupa instruksi penyeragaman Policy pemberian hak atas tanah kepada seorang WNI non Pribumi, masih belum definitif, masih bersifat instruksi, karena itu pelaksanaannya masih memerlukan adanya persetujuan dari Pejabat Tata Usaha Negara lainnya,seperti Badan Pertanahan Nasional dan sebagainya;

5.2.1.2 Bahwa dengan demikian objek gugatan tidak memenuhi syarat sebagai Keputusan Tata Usaha Negara sebagaimana dimaksud Pasal 1 angka 9 Undang-Undang Nomor 51 Tahun 2009 tentang Perubahan Kedua atas Undang-Undang Nomor 5 tahun 1986 tentang Peradilan Tata Usaha Negara, maka gugatan Penggugat haruslah dinyatakan tidak dapat diterima. ${ }^{17}$

5.2.2. Gugatan kabur dan tidak jelas (Obscuur Libel).

5.2.2.1 Penggugat mengajukan gugatan terhadap Instruksi Wakil Kepala Daerah Daerah Istimewa Yogyakarta Nomor : K.898/I/A/1975 tanggal 5 Maret 1975 berupa instruksi penyeragaman Policy pemberian hak atas tanah kepada seorang WNI non Pribumi, akan tetapi antara posita dan petitum gugatan tidak sinkron, posita gugatan berbelit-belit sehingga menjadikan keseluruhan gugatan menjadi tidak jelas dan tidak dapat dipahami maksud dan maknanya. Dalam gugatan antara title gugatan, posita dan petitum tidak sesuai, sehingga mengakibatkan gugatan menjadi kabur, oleh karena itu sudah sepatutnya apabila gugatan dalam perkara ini dinyatakan tidak dapat diterima.

${ }^{17}$ Farah Syah Rezah, Hukum Acara Peradilan Tata Usaha Negara, (Makasar: Social Politic Genius, 2018). Hlm. 42 
5.2.3. Gugatan kadaluwarsa/lewat waktu.šcepia. Berdasarkan Pasal 55 UndangUndang Nomor 5 Tahun 1986.

5.2.3.1 Peradilan Tata Usaha Negara, secara tegas dan jelas disebutkan bahwa : "Gugatan dapat diajukan hanya dalam tenggang waktu sembilan puluh hari terhitung sejak saat diterimanya atau diumumkannya Keputusan Badan atau Pejabat Tata Usaha Negara". 18

5.2.3.2. Objek sengketa merupakan putusan yang bersifat umum, oleh karenanya pemberitahuan dilakukan melalui Tambahan Lembaran Daerah Daerah Istimewa Yogyakarta Nomor 14 Tahun 1975 pada tanggal 5 Maret 1975, tenggang waktu sembilan puluh hari terhitung sejak saat diterimanya atau diumumkannya Keputusan Badan atau Pejabat Tata Usaha Negara, adalah :

5.2.3.2.1. Sembilan puluh hari sejak diumumkannya objek sengketa, maka gugatan seharusnya sudah didaftarkan maksimal pada tanggal 3 Juni 1975, Atau sembilan puluh hari sejak diundangkannya Undang-Undang No. 5 Tahun 1986 tentang Peradilan Tata Usaha Negara, maka gugatan seharusnya sudah didaftarkan maksimal pada tanggal 28 Maret 1987, Atau sembilan puluh hari sejak Penggugat mengajukan permohonan keberatan hak uji materiil terhadap Instruksi Wakil Kepala Daerah Daerah Istimewa Yogyakarta Nomor K.898/I/A/1975 kepada Mahkamah Agung Republik Indonesia pada tanggal 28 Januari 2015, maka gugatan seharusnya sudah didaftarkan maksimal

${ }^{18}$ Bambang Sugeng, Pengantar Hukum Acara Perdata \& Contoh Dokumen Litigasi Perkara Perdata, (Jakarta: Kencana, 2012). Hlm. 61 
pada tanggal 14 April 2015 sehingga gugatanya dianggap sebagai kadaluarsa.

Dilihat dari Perspektif Perbandingan, maka dalam hal ini Daerah Istimewa Yogyakarta bukanlah satu-satunya daerah istimewa di Indonesia dimana salah satunya adalah Daerah Istimewa Aceh, Aceh merupakan wilayah Indonesia yang memiliki peradaban Islam dengan sejarahnya yang panjang. Keberadaannya dalam peta sebaran Islam negeri ini amatlah vital. Tidak aneh jika Aceh seringkali dijuluki negeri Serambi Mekkah. Islam di sana telah berurat akar dan membentuk suatu daur kehidupan yang dipenuhi nuasa keagungan, kedua daerah istimewa tersebut memiliki kemiripan satu sama lain yakni tradisi yang mengikat kuat penduduknya, salah satu hal yang membuat Aceh istimewa adalah dari segi hukum pidananya dikarenakan penerapan hukum pidana di Aceh didasarkan pada pandangan ideologis keagamaan masyarakatnya, yakni agama Islam. ${ }^{19}$

Aceh dan Yogyakarta yang merupakan bagian dari Negara Kesatuan Republik Indonesia sudah seharusnya selaras hukumnya dengan falsafah yang dituangkan dalam Undang-Undang Dasar 1945 serta Pancasila, bila dipahami secara langsung maka seharusnya kedua daerah tersebut tidak boleh memiliki peraturan sendiri, namun harus diphami juga bahwa dalam Undang-Undang Dasar 1945 terdapat pengakuan masyarakat adat.

Pasal 18B ayat (2) UUD 1945 sebagai salah satu landasan konstitusional masyarakat adat menyatakan pengakuan secara deklaratif bahwa negara mengakui dan menghormati keberadaan dan hak-hak masyarakat hukum adat, masyarakat hukum adat disini adalah masyarakat hukum adat Aceh yang selama berabad-abad telah menetapkan syariat islam di wilayahnya memberikan jaminan kepastian hukum dalam segala urusan karena dasar kehidupan masyarakat Aceh yang religius telah membentuk

${ }^{19}$ Sunarji Hartono, Kapita Selekta Perbandingan Hukum, (Bandung: Citra Aditya Bakti, 1988). Hlm. 54 
sikap, daya juang yang tinggi, dan budaya Islam yang kuat serta Daerah Istimewa Yogyakarta yang dimana kekuasaan berputar pada wilayah keraton serta kekuasaan Sultan bertujuan untuk mewujudkan tata pemerintahan yang baik dan demokratis, ketenteraman dan kesejahteraan masyarakat, menjamin ke-bhinnekatunggal-ika-an, dan melembagakan peran dan tanggung jawab Kasultanan dan Kadipaten dalam menjaga dan mengembangkan budaya Yogyakarta yang merupakan warisan budaya bangsa.

Berkaitan dengan asas hukum Lex Specialis Derogat Legi Generalis yang dimana artinya hukum yang bersifat khusus mengesampingkan hukum yang bersifat umum. Pasca orde baru dan dilakukanya amandemen terhdapa Undang-Undang dasar tepatnya diatur dalam Pasal 18B UUD 1945 penguatan terhadap hukum lokal yang dimana isinya:

5.2.1. Negara Mengakui dan Menghormati satuan-satuan Pemerintahan yang bersifat khusus atau bersifat istimewa yang diatur dengan Undang-Undang.

5.2.2. Negara Mengakui dan menghromati kesatuan-Kesatuan Masyarakat Hukum adat beserta hak tradisionilnya sepanjang masih hidup dan perkembangan masyarakat dan prinsip negara kesatuan Republik Indonesia yang diatur dalam UndangUndang.

Perspektif Pasal 7 Undang-Undang Nomor 13 Tahun 2012, UndangUndang merupakan sarana maksimal bagi kesejahteraan spritul masyarakat maupun individu, melalui pembaharuan atau pelestarian. ${ }^{20}$ Dan bentuk pelestarian ini berupa Undang-Undang Keistimewaan Yogyakrta Nomor 13 Tahun 2012 yang disahkan pada tanggal 3 September 2012 negara mengakui dan menghormati satuan-satuan pemerintahan daerah yang bersifat khusus atau bersifat istimewa yang diatur dengan Undang-Undang, salah satu alasan

${ }^{20}$ Ellydar Chadir and Sudi Fahmi, Hukum Perbandingan Konstitusi, (Jakarta: Total Media, 2010). Hlm. 74 
terbesar mengapa Yogyakarta menjadi Daerah Istimewa karena jauh sebelum terbentuknya Negara Kesatuan Republik Indonesia, Yogyakarta telah berdiri dan mempunyai Pemerintahanya dan selama Indonesia memperjuangkan kemerdekaan Yogyakarta memeberikan sumbangsih yang sangat besar bagi berdirinya Negara Kesatauan Republik Indonesia, dan dengan diberikanya status istimewa maka didalamnya terdapat beberapa kewenangan yang didelegasikan pemerintah pusat kepada Yogyakarta yang sedikit berbeda dengan provinsi yang lain, bidang kewenangan yang diatur dalam Undang-Undang Keistimewaan Yogyakarta Pasal 7 yang isinya sebagai berikut:

5.2.1. Kewenangan DIY sebagai daerah otonom mencakup kewenangan dalam urusan Pemerintahan Daerah DIY sebagaimana dimaksud dalam undangundang tentang pemerintahan daerah dan urusan Keistimewaan yang ditetapkan dalam Undang-Undang ini.

5.2.2. Kewenangan dalam urusan Keistimewaan sebagaimana dimaksud pada ayat (1) meliputi:

5.2.2.1 Tata cara pengisian jabatan, kedudukan, tugas, dan wewenang Gubernur dan Wakil Gubernur;

\subsubsection{Kelembagaan Pemerintah Daerah DIY;}

\subsubsection{Kebudayaan;}

\subsubsection{Pertanahan; dan}

\subsubsection{Tata ruang.}

5.2.3. Penyelenggaraan kewenangan dalam urusan Keistimewaan sebagaimana dimaksud pada ayat (2) didasarkan pada nilai-nilai kearifan lokal dan keberpihakan kepada rakyat. 
5.2.4. Ketentuan lebih lanjut mengenai kewenangan dalam urusan Keistimewaan sebagaimana dimaksud pada ayat (2) dan ayat (3) diatur dengan Perdais. ${ }^{21}$

Dilihat dari perspektif Hak mengusai negara Larangan kepemilikan atas tanah bagi WNI keturunan melalui Surat. Edaran Gubernur. DIYPA.VIII/No.K.898/I/A 1975 merupakan sebuah hal yang sah dan legal berdasarkan pada Pasal 2 ayat (3) dan (4) Undang-Undang Peraturan Dasar pokok Agraria yang mepunyai isi sebgai berikut :

5.2.1. Wewenang yang bersumber pada hak menguasai dari Negara tersebut pada ayat (2) Pasal ini digunakan untuk mencapai sebesar-besar kemakmuran rakyat dalam arti kebangsaan, kesejahteraan dan kemerdekaan dalam masyarakat dan Negara hukum Indonesia yang merdeka, berdaulat, adil dan makmur.

5.2.2. Hak menguasai dari Negara tersebut di atas pelaksanaannya dapat dikuasakan kepada daerah-daerah Swatantra dan masyarakat-masyarakat hukum adat, sekedar diperlukan dan tidak bertentangan dengan kepentingan nasional, menurut ketentuan-ketentuan Peraturan Pemerintah. ${ }^{22}$

Pasal tersebut secara jelas telah menjelaskan bahwa Pemerintah pusat dapat memberikan wewenang pada pemerintah Daerah Istimewa Yogyakarta. ${ }^{23}$ Untuk memberlakukan larangan tersebut demi mewujudkan kesejahteraaan bagi rakyat pribumi yang berada di wilayah Yogyakarta yang telah lama hanya memiliki sebagian kecil tanah di Yogyakrta walaupun dalam jumlah penduduk Yogyakarta adalah mayoritas, tujuan negara adalah mensejahterakan rakyatnya dalam konsep negara kesejahteraan tujuan-tujuan pokok tersebut menurut konsep negara berideologi negara kesejahteraan, diperlukan keterlibatan dan intervensi negara (pemerintah) dalam bentuk

\footnotetext{
${ }^{21}$ Undang-Undang Nomor 13 Tahun 2012 tentang Keistimewaan Daerah Istimewa Yogyakrta

${ }^{22}$ Undang-Undang Nomor 5 Tahun 1960 tentang Pokok Agraria.

${ }^{23}$ Urip Santoso, Perolehan Ha Katas Tanah, (Jakarta: Kencana, 2015). Hlm. 15
} 
regulasi sehingga tujuan-tujuan tersebut dapat terwujud dalam berbagai aspek kehidupan masyarakat, khususnya melalui sektor pertanahan yang menguasai hajat hidup orang banyak sebagaimana telah dirumuskan secara eksplisit dalam Pasal 33 ayat (3) Undang-Undang Dasar Negara Republik Indonesia Tahun 1945 yang menyatakan bahwa "Bumi, air dan kekayaan alam yang terkandung di dalamnya dikuasai oleh negara untuk sebesar-besar kemakmuran rakyat.

Larangan kepemilikan tanah bagi WNI keturunan di Yogyakarta sebagai tindakan aktif negara/intervensi sehingga tujuan untuk mensejahterakan rakyat tercapai terutama dalam sektor pertanahan, bertujuan lebih kepada memberikan perlindungan terhadap tanah-tanah yang ada di Wilayah DIY agar tidak dikuasai oleh WNI non-pribumi. Jika dilihat dari data kependudukan di Yogyakarta, maka golongan etnis Tionghoa merupakan golongan ke-4 terbanyak di Wilayah DIY yang memang terkenal memiliki jiwa bisnis dan perdagangan yang sangat kuat,tanah oleh Boedi Harsono dimaknai sebagai karunia Tuhan Yang Maha Esa kepada Bangsa Indonesia, dan merupakan salah satu sumber utama bagi kelangsungan hidup dan penghidupan bangsa sepanjang masa dalam mencapai sebesar-besar kemakmuran rakyat yang adil dan merata. ${ }^{24}$

\subsection{Bentuk Kebijakan Yang Seharusnya Dikeluarkan Oleh Gubernur DIY Agar Dapat Memberikan Dasar Kewenangan atas Tindakanya}

Kewenangan yang dimiliki oleh Gubernur berdasarkan Pasal 7 Undang-Undang Keistimewaan Yogyakarta adalah Kewenangan dalam bidang pertanahan pertanahan dan tata ruang dan sudah dijelaskan dalam bahasan sebelumnya bahwa Yogyakarta adalah daerah istimewa sehingga dalam prakteknya Yogyakarta dapat memiliki hukum pertanahan sendiri yang sesuai dengan kebudayaan lokal dan dalam usaha mengimplentasikan

${ }^{24}$ Boedi Harsono, Menuju Penyempurnaan Hukum Tanah Nasional, (Jakarta: Universitas Trisakti, 2003). Hlm. 4 
budaya tersebut dalam bentuk tata perundangan di Indonesia yang didasarkan pada Undang-Undang Nomor 12 Tahun 2011 tentang Tata Cara Pembentukan Perundangan, Yogyakarta sebagai Daerah Istimewa sesuai dengan yang diamanatkan oleh Undang-Undang Keistimewaan Yogyakarta yang memiliki keunikan tersendiri dari wilayah lain.

Peraturan daerah memiliki bentuk berbeda dengan daerah lain ini sudah dituangkan dalam Pasal 46 huruf (e) Undang-Undang Nomor 13 Tahun 2012 tentang Keistimewaan Daerah Istimewa Yogyakarta, maka perlu menetapkan Peraturan Daerah tentang Tata Cara Pembentukan Peraturan Daerah Istimewa yang berwujud pada tahun 2013 dalam Peraturan Daerah Daerah Istimewa Yogyakarta Tentang cara Pembentukan Peraturan Daerah Istimewa Nomor 1 Tahun 2013, dalam bentuk Peraturan Daerah Istimewa inilah seharusnya larangan hak milik tanah atas tanh bagi WNI keturunan harus dituangkan agar sesuai dengan hierarki dan tata cara pembentukan perundagan yang berlaku di Indonesia.

\section{Kesimpulan}

6.1. Rasio legis keluarnya surat edaran larangan hak milik atas tanah di Yogyakarta dapat dijelaskan melalui 3 (tiga) alasan yakni landasan yuridis yang didasarkan sejak dahulu memang ada larangan pengasingan tanah bagi orang asing di Daerah istimewa Yogyakrta, sedangakan alasan filosofis berpatokan pada ketidakadilan akan distribusi tanah yang diman merugikan rakyat pribumi, diperparah dengan Wilayah Yogyakarta yang sempit serta faktor WNI keturunan yang baru menjadi warga negara Indonesia sepenuhnya jauh setelah kemerdekaan Indonesia sehingga masih dianggap sebagai asing oleh masyarakat Yogyakrta, alasan sosiologis merupakan jawaban dari alasan filosifis dan normatif yakni melalui intervensi pemerintah daerah berupa moratorium demi mengembalikan keseimbangan sehingga akses masayarakat pribumi terhdap tanah di Yogayakarta lebih mudah. 
6.2. Sahnya surat Edaran larangan bagi warga keturunan akan hak milik atas tanah sudah dibuktikan melaui Putusan Mahkamah Agung Nomor 179 K/TUN/2017 yang dimana memenangkan Pemerintah DIY, serta dibandingakan dengan Daerah Istimewa lain yakni Aceh yang memilki peraturan yang berbeda dengan wilayah lain lalu dilanjutkan dengan kewenangan yang diberikan Undang-Undang Nomor 13 Tahun 2012 tentang Keistimewaan Yogyakarta yang memberi wewenag dalam bidang pertanahan, dan untuk memberikan akses bagi warga pribumi untuk mendapatkan tanah di Yogyakarta maka dilihat juga dari perspektif hak menguasai Negara demi mensejahterkan rakyat.

6.3. Bentuk kebijakan yang seharusnya dikeluarkan oleh pemerintah Yogyakarta sesuai dengan yang diamanatkan dalam Undang-Undang Keistimewaan Yogyakarta adalah dalm Bentuk Perdais, yang dimana tata cara pembentukan Perdais tertuang dalam Peraturan Daerah Daerah Istimewa Yogyakarta Tentang cara Pembentukan Peraturan Daerah Istimewa Nomor 1 tahun 2013. 


\section{DAFTAR PUSTAKA}

\section{Buku}

A. Mukti Arto. Konsepsi Ideal Mahkamah Agung Redefinisi Peran Dan Fungsi Mahkamah Agung Untuk Membangun Indonesia Baru,. Yogyakarta: Pustaka Pelajar, 2001.

Andrey Sujatmoko. Hukum HAM Dan Hukum Humaniter. Jakarta: Raja Grafindo Persada, 2015.

Bambang Sugeng. Pengantar Hukum Acara Perdata \& Contoh Dokumen Litigasi Perkara Perdata,. Jakarta: Kencana, 2012.

Boedi Harsono. Menuju Penyempurnaan Hukum Tanah Nasional,. Jakarta: Universitas Trisakti, 2003.

Carakatama, Sabda. Sejarah Keraton Yogyakarta. Yogyakarta: Narasi, 2019.

Chadir, Ellydar, and Sudi Fahmi. Hukum Perbandingan Konstitusi, . Jakarta: Total Media, 2010.

E.Fernando Manullang. Menggapai Hukum Berkeadilan. Jakarta: Kompas Gramedia, 2016.

Farah Syah Rezah. Hukum Acara Peradilan Tata Usaha Negara,. Makasar: Social Politic Genius, 2018.

John Rabe. Equality, Affirmative Action And Justice,. Hamburg: Books on Demand GMBH, 2001.

Mochamad Tauhid. Masalah Agraria Di Indonesia. Yogyakarta: STPNpress, 2009.

Mullen Elizabeth. Compensatory Justice, The Oxford Handbook of Justice in the Workplace,. Oxford: Chapter, 2015.

Nur Asyiah. Hukum Administrasi Negara. Yogyakarta: Deepublish, 2018.

Sudargo Gautama. Hukum Agraria Antar Golongan. Bandung: Alumni, 1973.

Sunarji Hartono. Kapita Selekta Perbandingan Hukum,. Bandung: Citra Aditya Bakti, 1988.

Urip Santoso. Perolehan Ha Katas Tanah, . Jakarta: Kencana, 2015. 


\section{Artikel Jurnal}

Anggraeni, Tyas Dian. "Interaksi Hukum Lokal Dan Hukum Nasional Dalam Urusan Pertanahan Di Daerah Istimewa Yogyakarta,." Jurnal Rechstfinding Media Pembinaan Hukum Nasional, 1, no. 1 (2012).

Syafa'at, Rachmad. "Politik Hukum Dan Hak-Hak Masyarakat Adat Terhadap Akses Sumber Daya Alam,." Cakrawala Hukum 1, no. 2 (2011).

\section{Thesis}

Linda Arthaputri Kurniadewi. "Pelaksanaan Surat Edaran Gubernur DIY PA.VIII/NO.K.898/I/A/1975 Tentang Larangan Kepemilikan Tanah Hak Milik Bagi Wni Non Pribumi Di Kabupaten Sleman,." Universitas Gadjah Mada, 2015.

\section{Peraturan Perundang-Undangan}

Undang-Undang Nomor 13 tahun 2012 tentang Keistimewaan Daerah Istimewa Yogyakrta.

Undang-Undang Nomor 5 Tahun 1960 tentang Pokok Agraria.

Surat Edaran Gubernur Daerah Istimewa Yogyakarta PA.VIII/No.K.898/I/A

1975 tentang Larangan Kepemilikan Tanah Hak Milik Bagi Wni Nonpribumi.

\section{Internet}

Pemerintah Daerah Daerah Istimewa Yogyakarta. "Luas Wilayah," 2019. https://jogjaprov.go.id/berita/detail/luas-wilayah. 